A SPECIAL ISSUE FOR THE $6^{\text {TH }}$ SCIENTIFIC INTERNATIONAL CONFERENCE

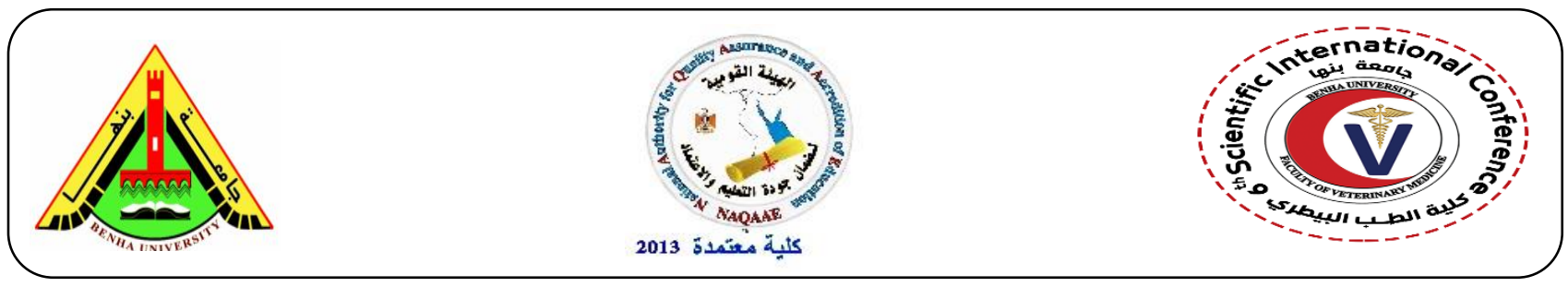

\title{
In Vitro Study of Anticancer Effect of N Acetyl Cysteine-Metal Complexes as New Target Drugs on Human Cancer Cell Lines
}

\author{
Omayma A. R. AbouZaid ${ }^{1}$, Eman Noaman², Shaimaa abdelAti ${ }^{3}$, Gehad Genidy Mohamed ${ }^{\mathbf{4}}$ \\ ${ }^{1}$ Biochemistry Department, Faculty of Vet. Med. Moshtohor, Benha University, Egypt. \\ ${ }^{2}$ Radiation Biology Department, National Center for Radiation Research and Technology (NCRRT), \\ Atomic Energy Authority, Egypt. \\ ${ }^{3}$ Inorganic Chemistry Dept., Faculty of Science, Cairo University. 4 Post graduate student
}

\begin{abstract}
A B S T R A C T
One of the main methods of modern cancer treatment is drug therapy but, it is found to be difficult to cure effectively. N-acetylcysteine (NAC), which is a membrane-permeable metal-binding compound, might have anti-cancer activity in the presence of different metals. In the present study synthesis of NAC with ( $\mathrm{Cu}, \mathrm{Zn}, \mathrm{Cd}, \mathrm{Fe}, \mathrm{Mg}, \mathrm{Mn}, \mathrm{Cr}, \mathrm{Ni}, \mathrm{Co}, \mathrm{Se}$ and $\mathrm{Ag})$ by metals investigation and the formation of these complexes by IR, NMR. The effect of cytotoxicity of these complexes on Breast, Liver, Prostate and Ovary human cancer cell lines were evaluated. The best complexes were seen in cadmium $\mathrm{N}$ acetyl cysteine complex in breast, ovary, prostate and liver cell line.
\end{abstract}

Key Words: N acetyl cysteine, metal complexes, IR, NMR, human cancer cell line.

(http://www.bvmj.bu.edu.eg)

(BVMJ-34(3): 206-217, 2018)

\section{INTRODUCTION}

cancer. Oxygen is an absolute necessity for life and it is also the worst carcinogenic molecule that we must endure during all our lifetime. This means that we must be careful to always manage a good reserve of intracellular reducing potential. In fact, metal-ions based compounds have the abilities to coordinate ligands in a three-dimensional configuration (Domingo

,1994), and provide suitable environment for various molecular structures that confer different geometries and kinetic properties that cannot be recognized by carbon-based
$\mathrm{N}$ Acetyl Cysteine is an antioxidant containing an acetylated form of the amino acid L-cysteine that functions as a precursor of glutathione synthesis. Glutathione is an important thiol involved in cellular detoxification (Meister and Anderson1983). The presence of sulfhydryl groups in NAC also enables the neutralization of free radicals. Metals are able to induce cancer and to treat cancer! Some of them are even able to perform both, almost all metals are able to generate reactive oxygen species (ROS), this property explains a great part of both their carcinogenicity and their aptitude to treat 
gentamycin and $0.25 \%$ Trypsin-EDTA were purchased from Lonza.

2.2. Preparations and Measurements of $\mathrm{N}$ Acetyl Cysteine metal complexes:

Mixed metal complexes of $\mathrm{N}$ acetyl cysteine as a primary ligand with metal ions $(\mathrm{Zn}, \mathrm{Ni}$, $\mathrm{Cu}, \mathrm{Cd}, \mathrm{Fe}, \mathrm{Mn}, \mathrm{Cr}, \mathrm{Ni}, \mathrm{Mg}, \mathrm{Co}, \mathrm{Ag}$ and $\mathrm{Se}$ ) were synthesized. The prepared complexes were characterized by IR and NMR as shown in figures (1-16).

\subsection{Cell line Propagation: MCF-7 cells} (human breast cancer cell line, HepG-2 cells (human Hepatocellular carcinoma), PC-3 (prostatic carcinoma) and CHO-K1 (Ovary carcinoma) were obtained from VACSERA Tissue Culture Unit and were propagated in Dulbecco's modified Eagle's medium (DMEM) supplemented with $10 \%$ heatinactivated fetal bovine serum, $1 \%$ Lglutamine, HEPES buffer and $50 \mu \mathrm{g} / \mathrm{ml}$ gentamycin. All cells were maintained at $37^{\circ} \mathrm{C}$ in a humidified atmosphere with $5 \% \mathrm{CO}_{2}$ and were sub-cultured two times a week.

\subsection{Cytotoxicity evaluation using viability} assay: For cytotoxicity assay, the cells were seeded in 96-well plate at a cell concentration of $1 \times 10^{4}$ cells per well in $100 \mu 1$ of growth medium. Fresh medium containing different concentrations of the test sample were added after $24 \mathrm{~h}$ of seeding. Serial two-fold dilutions of the tested chemical compound were added to confluent cell monolayers dispensed into 96-well, flat-bottomed microtiter plates (Falcon, NJ, USA) using a multichannel pipette. The microtiter plates were incubated at $37^{\circ} \mathrm{C}$ in a humidified incubator with $5 \%$ $\mathrm{CO}_{2}$ for a period of $48 \mathrm{~h}$. Three wells were used for each concentration of the test sample. Control cells were incubated without test sample and with or without DMSO. The little percentage of DMSO present in the wells (maximal $0.1 \%$ ) was found not to affect the chemical drugs (Simon,2007). According to Domingo (Cohen ,2007), metals could be divided into four groups: (1) metals with greatest toxicity that are widespread in the environment (arsenic, cadmium, lead, mercury, and uranium); (2) essential trace metals (chromium, cobalt, manganese, selenium, and zinc); (3) other metals with biological importance (nickel and vanadium); and (4) metals of pharmacological interest (aluminum, gallium, and lithium). Copper is an essential trace element for humans, but it becomes toxic at high concentration. Copper's major functions within metallo-enzymes are oxidation-reduction reactions, in which it reacts directly with molecular oxygen to produce ROS through Haber-Weiss reactions. In the form of bivalent ions, copper is poisonous to lower organisms, as bacteria, algae, fungus. The binding of copper (II) ions to specific sites can modify the structures of DNA it binds to DNA, with higher affinity than any other divalent cation, and then promotes DNA oxidation.

Aim of the work: synthesis of new drugs which have anticancer potential against different cell lines low side effects.

\section{2-MATERIAL AND METHODS}

2.1-Chemicals: N-Acetyl Cysteine purchased from (Sigma, USA). N-acetyl cysteine, [ Copper, Selenium, Cadmium, Ferric, Zinc, Manganates, Magnesium, Cobalt, Nickel, silver and chromium] chlorides were purchase from (Sigma, USA). Ethanol, ammonia from Egyptian

company for chemicals). Dimethyl sulfoxide (DMSO), crystal violet and trypan blue dye were purchased from Sigma (St. Louis, Mo., USA). Fetal Bovine serum, DMEM, RPMI1640, HEPES buffer solution, L-glutamine, 
number of viable cells and the percentage of viability was calculated as [1(ODt/ODc)]x100\% where ODt is the mean optical density of wells treated with the tested sample and ODc is the mean optical density of untreated cells. The relation between surviving cells and drug concentration is plotted to get the survival curve of each tumor cell line after treatment with the specified compound. The $50 \%$ inhibitory concentration ( $\left.\mathrm{IC}_{50}\right)$, the concentration required to cause toxic effects in $50 \%$ of intact cells, was estimated from graphic (Mosmann ,1983).

\section{RESULTS:}

Mixed metal complexes of $\mathrm{N}$ acetyl cysteine as a primary ligand with metal ions [zinc, Copper, Iron, Nickel, Cobalt, Magnesium, Manganese, Selenium and cadmium] were synthesized. The prepared complexes were characterized by IR and NMR as shown in figures (1-17). The inhibitory effect of metal complexes on (MCF-7, HepG2, PC3, CHO-K) were shown in tables (1-4). The best complex was (NAC+ $\mathrm{Cd}$ ) against MCF7(Breast cancer) IC50 was $11.2 \mu \mathrm{g} / \mathrm{ml}$. experiment. After incubation of the cells for at $37^{\circ} \mathrm{C}$, various concentrations of sample were added, and the incubation was continued for $24 \mathrm{~h}$ and viable cells yield was determined by a colorimetric method.

In brief, after the end of the incubation period, media were aspirated and the crystal violet solution (1\%) was added to each well for at least 30 minutes. The stain was removed, and the plates were rinsed using tap water until all excess stain is removed. Glacial acetic acid (30\%) was then added to all wells and mixed thoroughly, and then the absorbance of the plates was measured after gently shaken on Microplate reader (TECAN, Inc.), using a test wavelength of $490 \mathrm{~nm}$. All results were corrected for background absorbance detected in wells without added stain. Treated samples were compared with the cell control in the absence of the tested compounds. All experiments were carried out in triplicate. The cell cytotoxic effect of each tested compound was calculated. The optical density was measured with the microplate reader (Sun Rise, TECAN, Inc, USA) to determine the

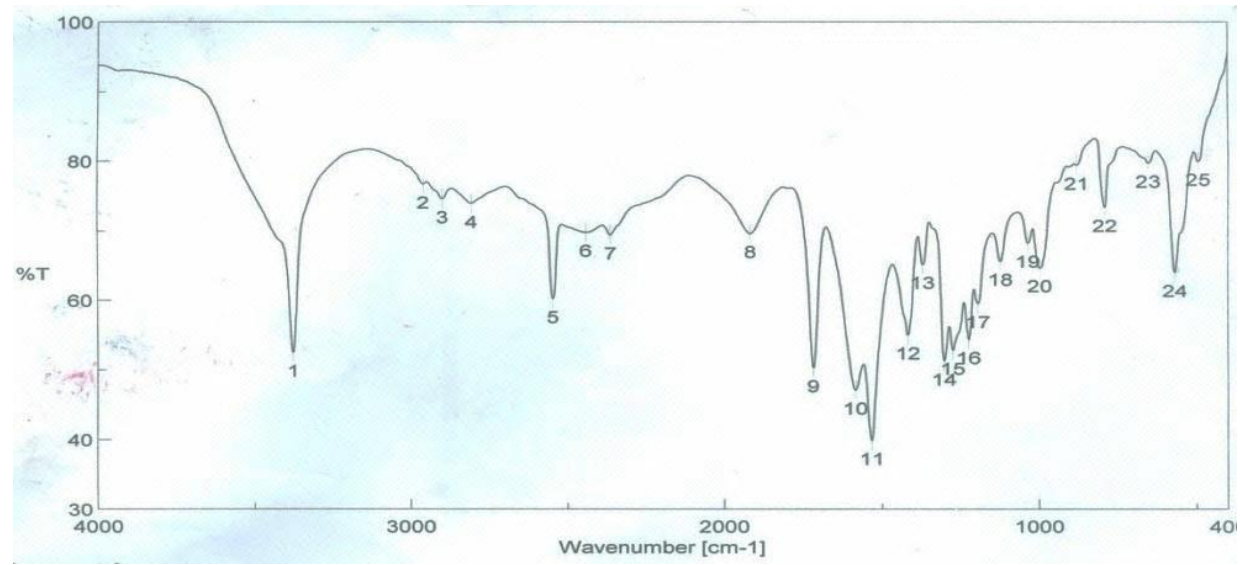

Fig.1. Infra-red of N Acetyl Cysteine 
In Vitro Study of Anticancer Effect of N Acetyl Cysteine -Metal Complexes as New Target Drugs on Human Cancer Cell Lines

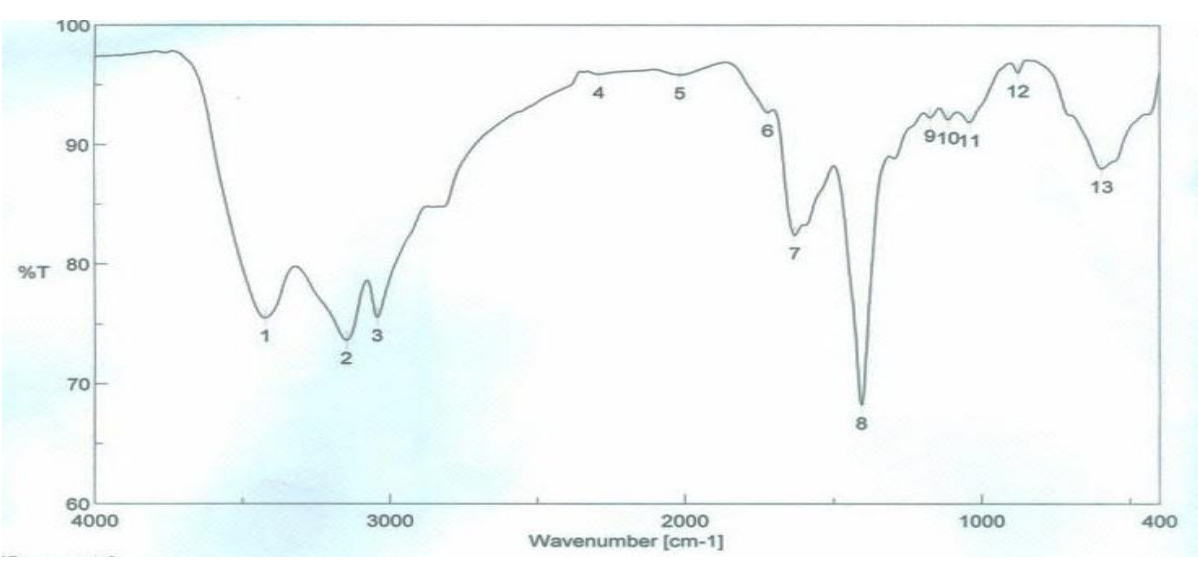

Fig.2.Infra-red of (N Acetyl Cysteine +Iron)

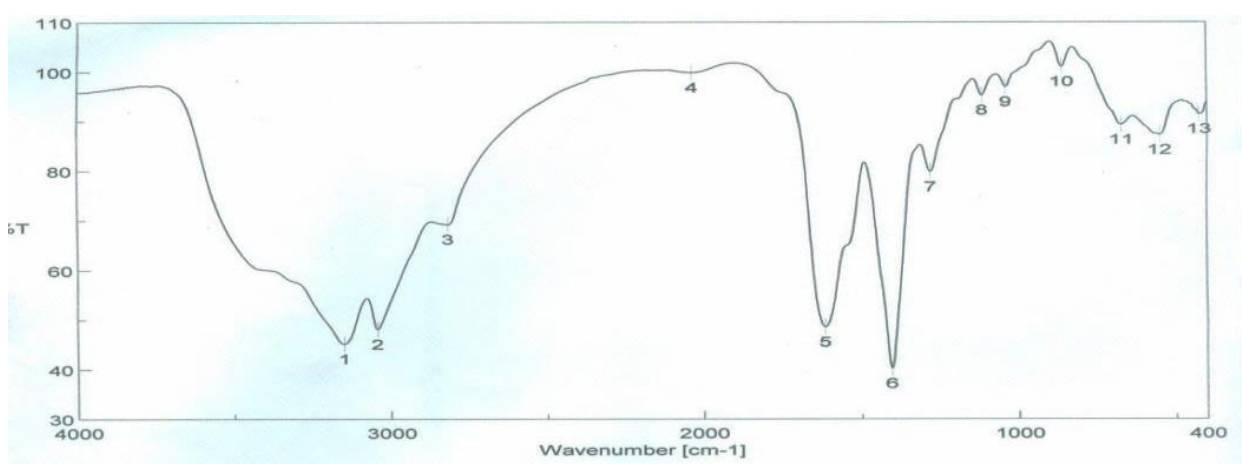

Fig.3.Infra-red of (N Acetyl Cysteine +Zinc)



Fig.4. Infra-red of (N Acetyl Cysteine +Silver) 


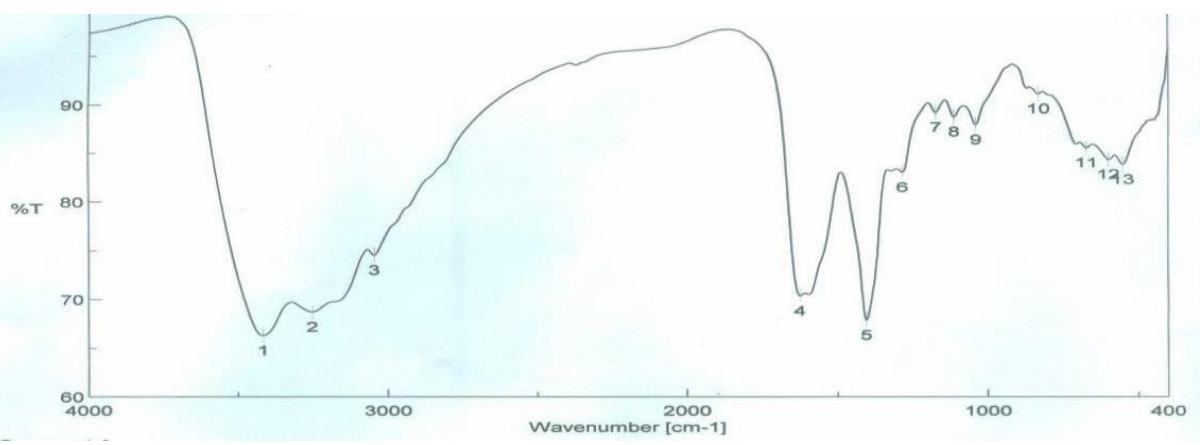

Fig.5.Infra-red of (N Acetyl Cysteine +Cobalt)

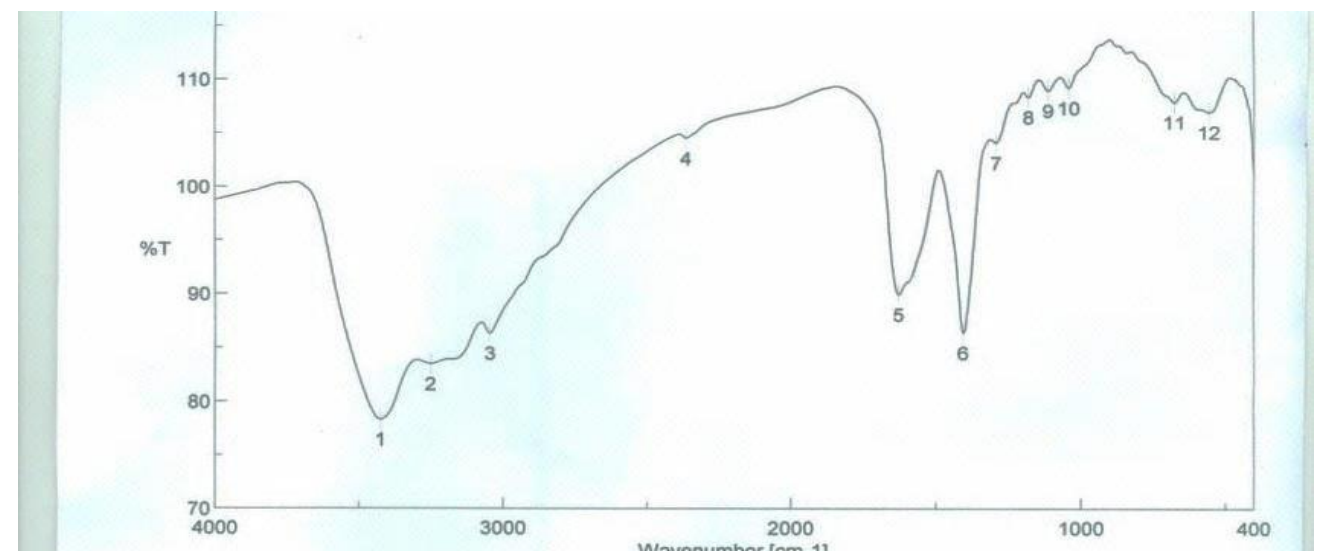

Fig.6.Infra-red of (N Acetyl Cysteine+ Nickel)

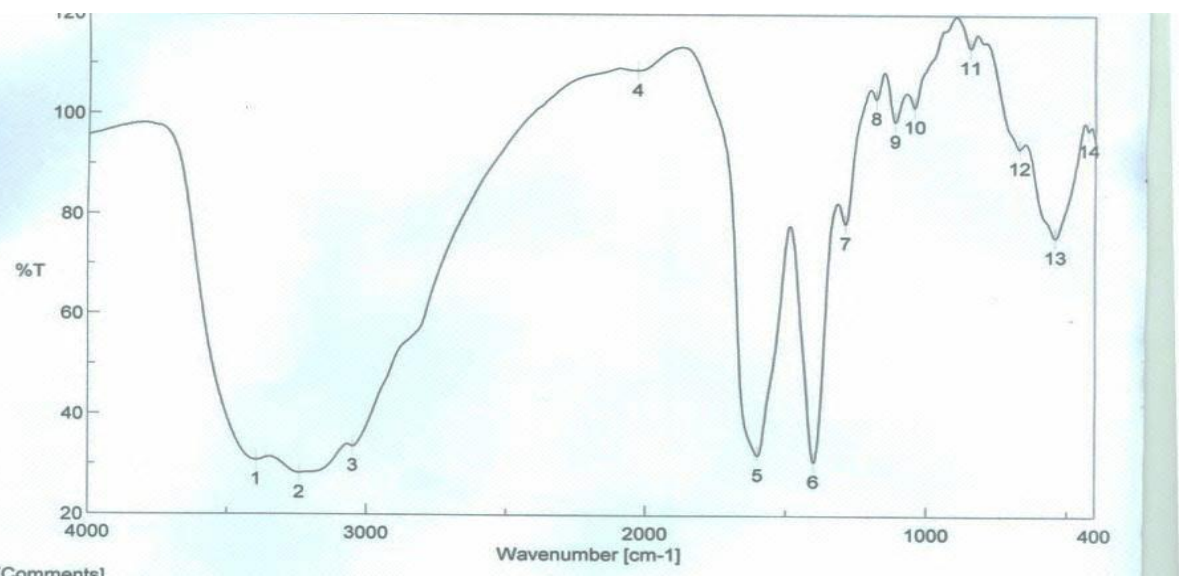

Fig.7. Infra-red of (N Acetyl Cysteine+ Chromium) 
In Vitro Study of Anticancer Effect of N Acetyl Cysteine -Metal Complexes as New Target Drugs on Human Cancer Cell Lines

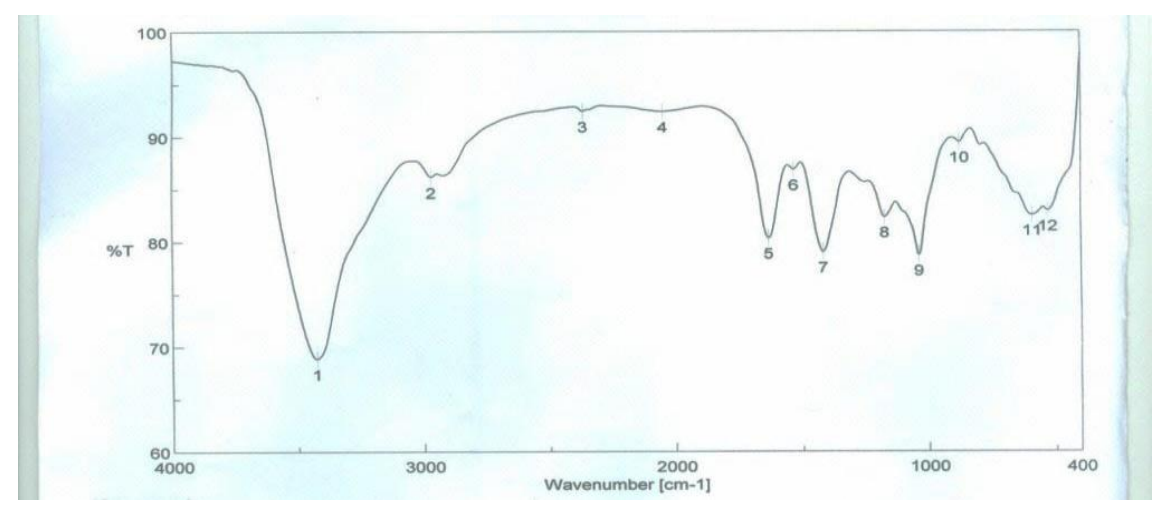

Fig.8.Infrared of (N Acetyl Cysteine+ Copper)

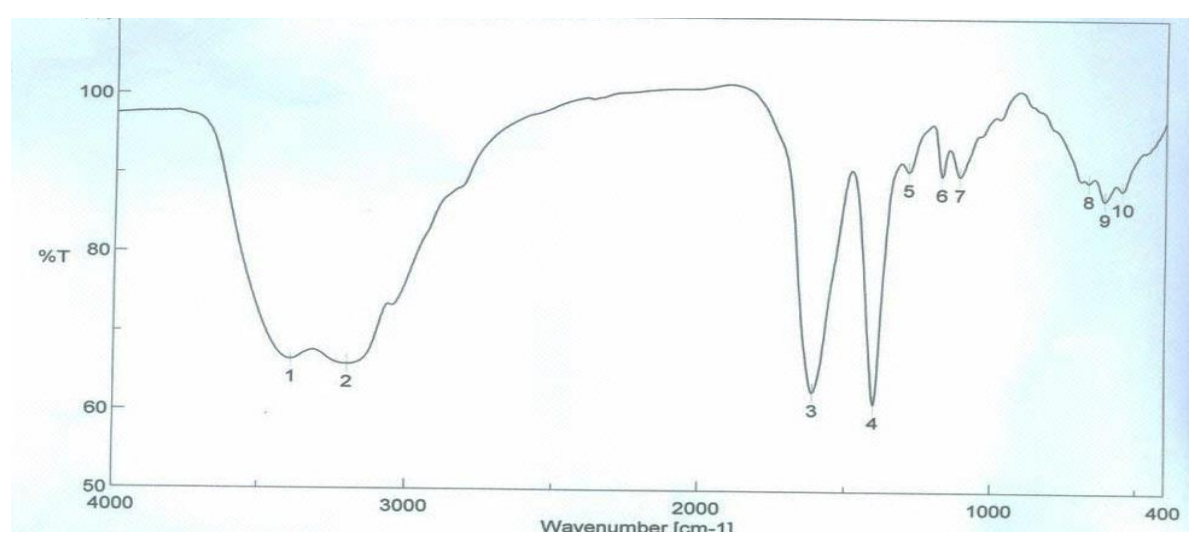

Fig.9.Infra-red of (N Acetyl cysteine +Manganese)



Fig.10.Infra-red of (N Acetyl Cysteine +Cadmium) 


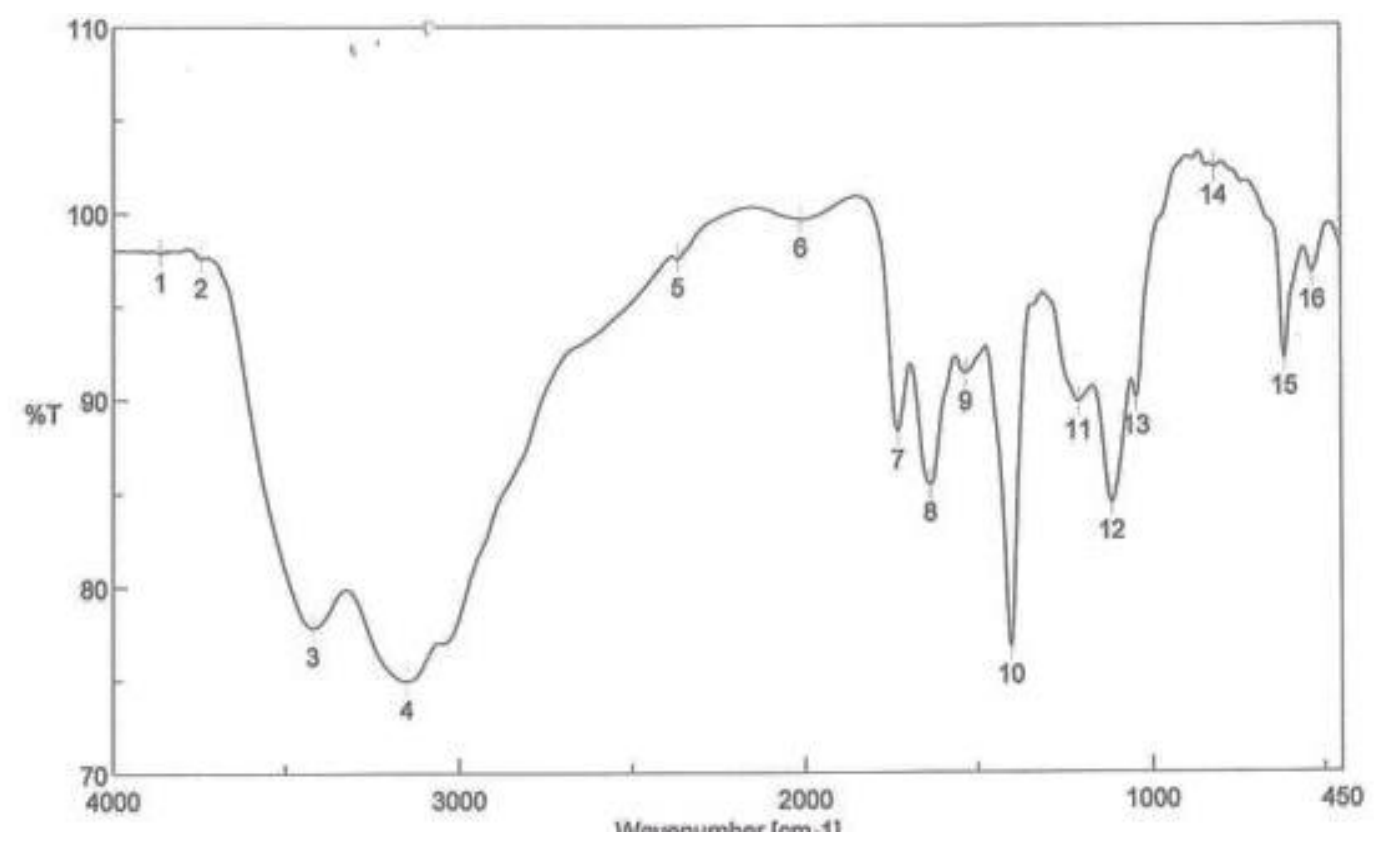

Fig.11.Infra-red of (N Acetyl Cysteine + Selenium)

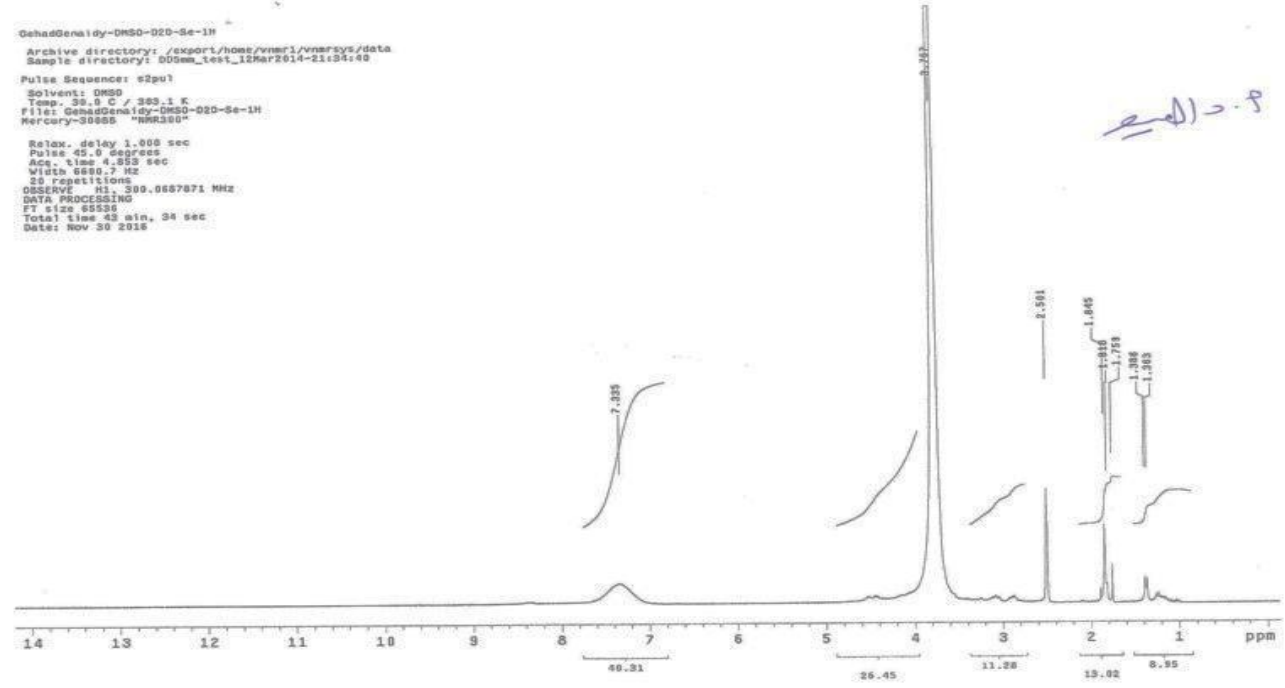

Fig.12. Nuclear magnetic resonance of (N Acetyl Cysteine) 
In Vitro Study of Anticancer Effect of N Acetyl Cysteine -Metal Complexes as New Target Drugs on Human Cancer Cell Lines

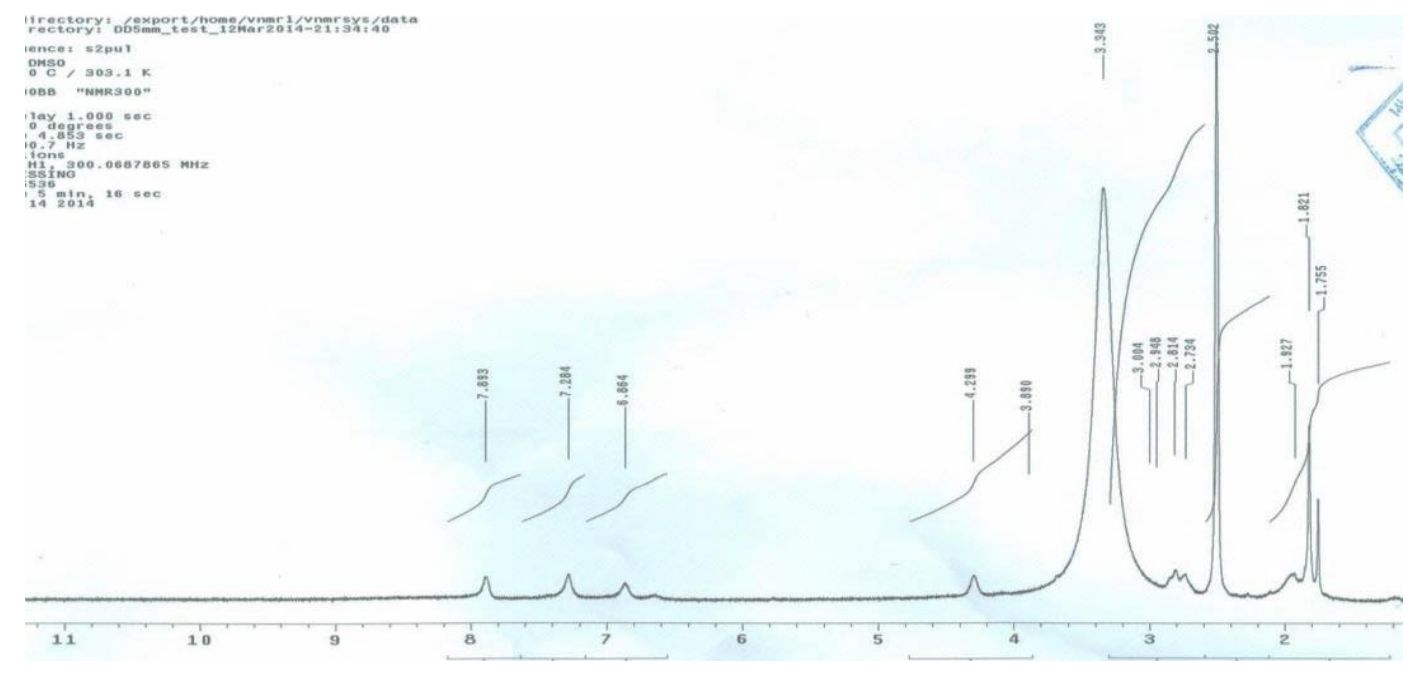

Fig.13.Neucluar magnetic resonance of (N Acetyl Cysteine +Cupper)

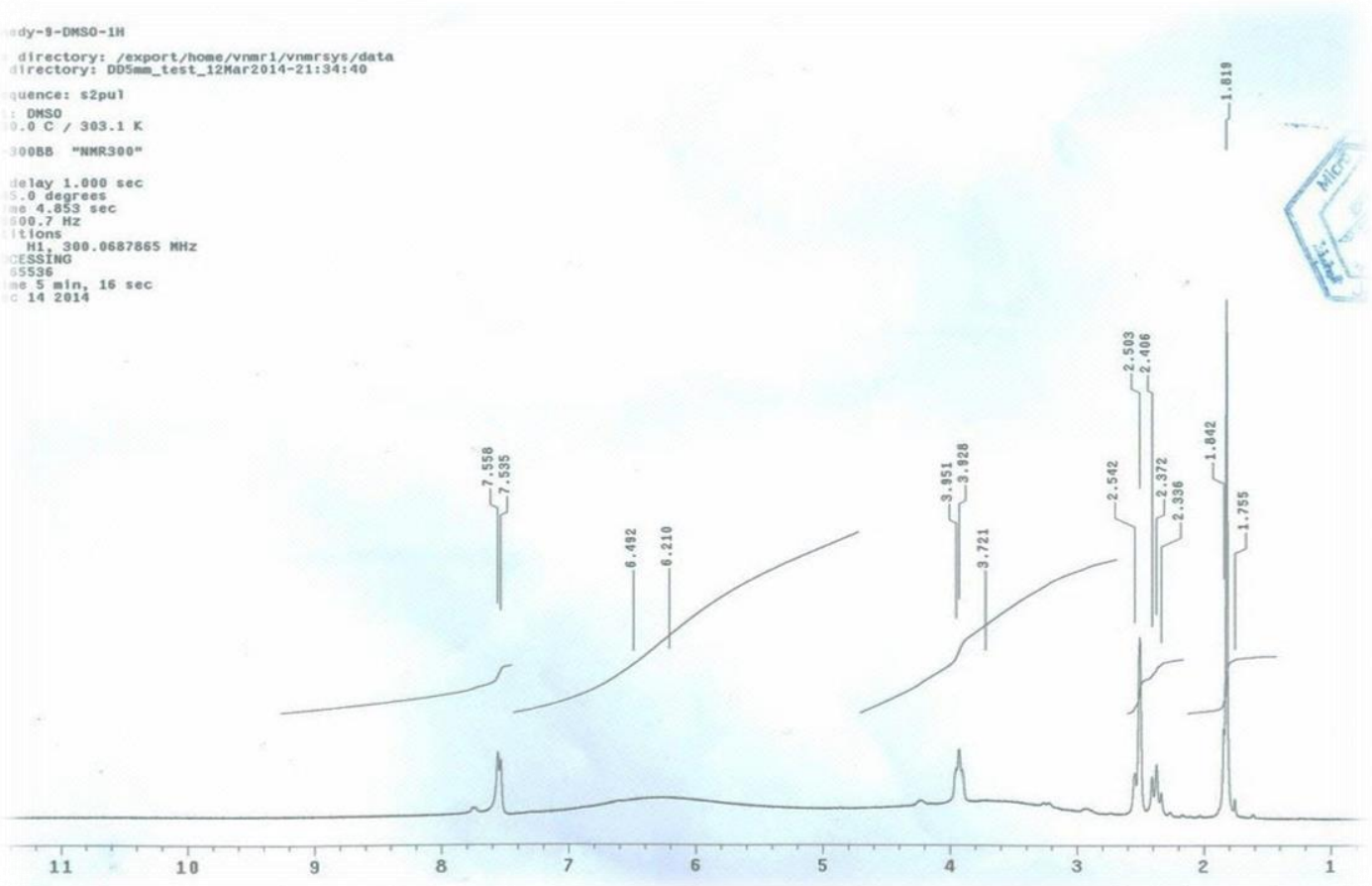

Fig.14. Nuclear magnetic resonance of (N Acetyl Cysteine + Manganese) 


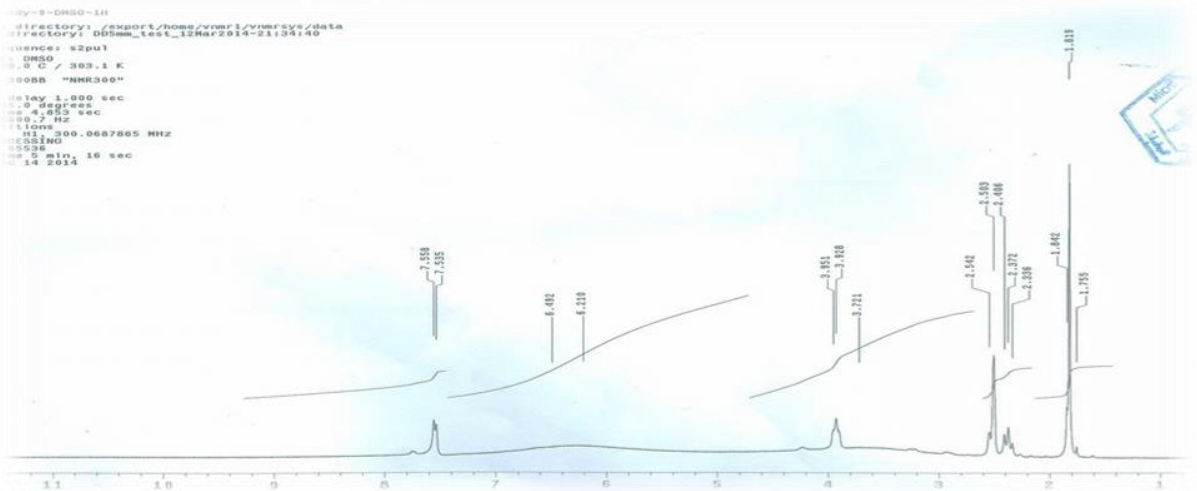

Fig.15.Neuclear magnetic resonance of (N Acetyl Cysteine +Zinc)

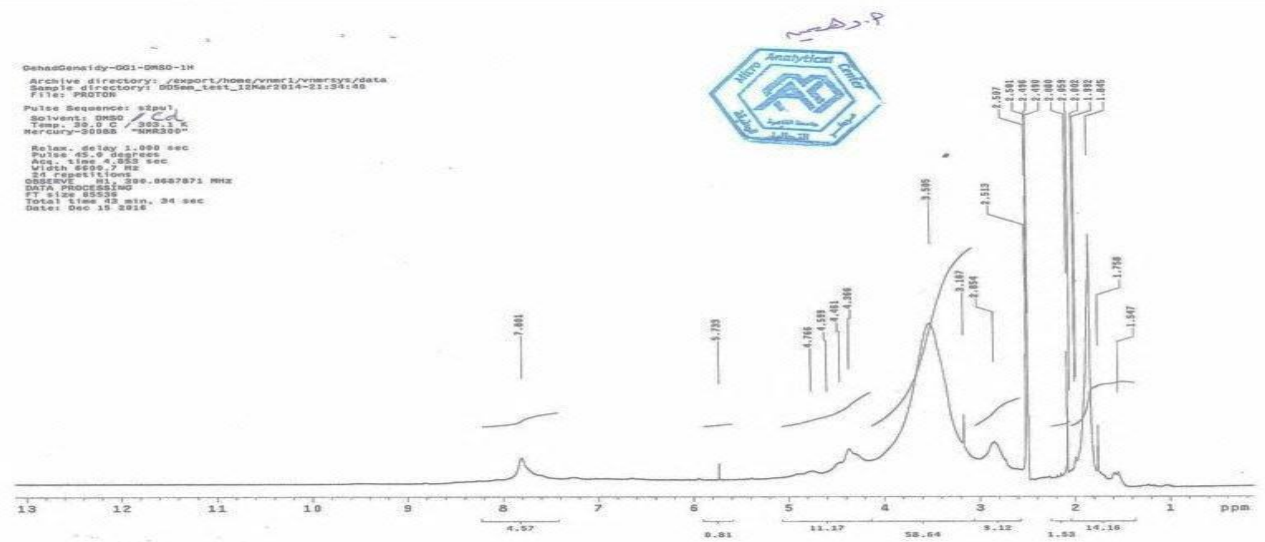

Fig.16.Neuclear magnetic resonance of (N Acetyl Cysteine +Cadmium)

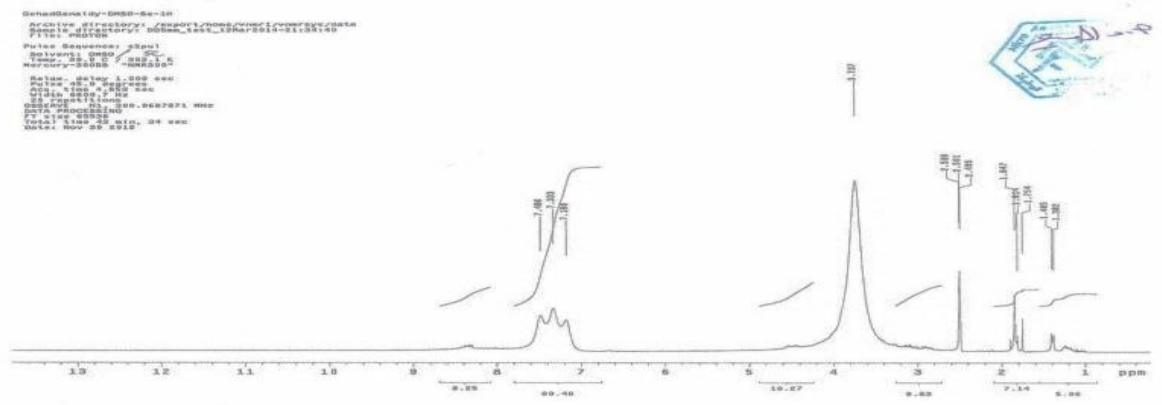

Fig.17. Nuclear magnetic resonance of (N Acetyl Cysteine +Selenium) 
Table. 1. Inhibitory activity against Breast carcinoma cells (MCF-7).

\begin{tabular}{lc}
\hline Complexes & IC50 \\
\hline $\mathrm{NAC}$ & No inhibitory activity \\
$\mathrm{NAC}+\mathrm{Fe}$ & $\mathrm{IC}_{50}=31.7 \mu \mathrm{g}$ \\
$\mathrm{NAC}+\mathrm{Zn}$ & $\mathrm{IC}_{50}=82.4 \mu \mathrm{g}$ \\
$\mathrm{NAC}+\mathrm{Cu}$ & $\mathrm{IC}_{50}=44.4 \mu \mathrm{g}$ \\
$\mathrm{NAC}+\mathrm{Se}$ & $\mathrm{IC}_{50}=397 \mu \mathrm{g} / \mathrm{ml}$ \\
$\mathrm{NAC}+\mathrm{Ag}$ & $\mathrm{IC}_{50}=40 \mu \mathrm{g}$. \\
$\mathrm{NAC}+\mathrm{Cr}$ & No inhibitory activity $_{\mathrm{NAC}+\mathrm{Co}}$ \\
$\mathrm{NAC}+\mathrm{Ni}$ & $\mathrm{IC}_{50}=>100 \mu \mathrm{g}$ \\
$\mathrm{NAC}+\mathrm{Cd}$ & $\mathrm{IC}_{50}=>100 \mu \mathrm{g}$ \\
$\mathrm{NAC}+\mathrm{Mn}$ & $\mathrm{IC}_{50}=11.2 \mu \mathrm{g}$. \\
$\mathrm{NAC}+\mathrm{Cd}+\mathrm{Fe}$ & $\mathrm{IC}_{50}=94.9 \mu \mathrm{g}$ \\
\hline
\end{tabular}

Table .2. Inhibitory activity against liver carcinoma (HepG2).

\begin{tabular}{ll}
\hline \multicolumn{1}{c}{ Complexes } & \multicolumn{1}{c}{ IC50 } \\
\hline$[\mathrm{NAC}+\mathrm{Cd}]$ & $\mathrm{IC}_{50}=112 \mu \mathrm{g} / \mathrm{m}$ \\
{$[\mathrm{NAC}+\mathrm{Cu}]$} & $\mathrm{IC}_{50}=>500 \mu \mathrm{g} / \mathrm{ml}$ \\
{$[\mathrm{NAC}+\mathrm{Se}]$} & $\mathrm{IC}_{50}=>500 \mu \mathrm{g} / \mathrm{ml}$ \\
\hline
\end{tabular}

Table .3. Inhibitory activity against prostate carcinoma (PC3)

\begin{tabular}{lc}
\hline Complexes & IC50\% \\
\hline$[\mathrm{NAC}+\mathrm{Cd}]$ & $1 \mathrm{IC}_{50}=356 \mu \mathrm{g} / \mathrm{ml}$. \\
{$[\mathrm{NAC}+\mathrm{Cu}]$} & $1 \mathrm{IC}_{50}=>500 \mu \mathrm{g} / \mathrm{ml}$. \\
{$[\mathrm{NAC}+\mathrm{Se}]$} & $1 \mathrm{IC}_{50}=362 \mu \mathrm{g} / \mathrm{ml}$. \\
\hline
\end{tabular}

Table .4. Inhibitory activity against Ovary cancer CHO-K.

\begin{tabular}{lc}
\hline Complexes & IC50\% \\
\hline$[\mathrm{NAC}+\mathrm{Cd}]$ & $I C_{50}=335 \mu \mathrm{g} / \mathrm{ml}$. \\
{$[\mathrm{NAC}+\mathrm{Cu}]$} & $I C_{50}=>500 \mu \mathrm{g} / \mathrm{ml}$. \\
{$[\mathrm{NAC}+\mathrm{Se}]$} & $I C_{50}=438 \mu \mathrm{g} / \mathrm{ml}$. \\
\hline
\end{tabular}




\section{DISSCUSION:}

lesion, in human leukemia cell line HL-60, whereas the amount of 8-oxodG in HP100, which is a hydrogen peroxide (H2O2)resistant cell line derived from HL-60, was not increased, $\mathrm{N}$-acetylcysteine plus $\mathrm{Cu}$ II) frequently modified thymine and guanine residues (Kasai et al., 1992). By designing metals with ligand and study the effect of these on (MCF-7, HepG2, PC3 and CHO-K), we reported that some of these complexes do not have any inhibitory activity effect (NAC, NAC-Cr). While (NAC-Ni and NAC-Co) showed weak inhibitory effect. Other effective (NAC-Cd, NAC-Fe, NAC-Cu and NAC-Ag) on MCF-7. While, interaction of $\mathrm{Cd}$ with $\mathrm{Fe}$ was effective on MCF-7. On HepG2 (NAC$\mathrm{Cu})$ has weak inhibitory activity. while, (NAC-Cd, NAC-Se) have inhibitory activity. On PC3 and CHO-K $\mathrm{Cd}$ and $\mathrm{Se}$ have inhibitory activity while, NAC-Cu weak inhibitory activity. So, from the obtained results according the design of theses complexes we consider $\mathrm{N}$ Acetyl Cysteine with cadmium a strong drug recommended for treating of breast carcinoma.

\section{REFERENCES}

Cohen sethM.(2007).New approaches for medicinal applications of bioinorganic chemistryCurrent Opinion in Chemical BiologyVolume 11, Issue 2, Pages 115-120.

Domingo, J.L. (1994). Metal-induced developmental toxicity in mammals: a review. J. Toxicol. Environ. Health.;42: 123-141.

Frezza M, Hindo S, Chen D, Davenport A, Schmitt S, Tomco D and Dou QP. (2010). Novel metals and metal complexes as platforms for cancer therapy. Curr Pharm Des.;16(16):1813-25.
The discovery and development of new anticancer agents are crucial to prevent side effects and drug resistance problems caused by current available treatments (Zhang et al.,2007). Metal complexes with active drugs as ligand is a research area of increasing interest for inorganic and medicinal chemistry and has concentrated much attention as an approach to new drug development (Renzo,2000). The most important factor in maintenance of cellular redox homeostasis is thiol group $(-\mathrm{SH})$ containing molecules. In aqueous solution, metal ions exist as positively charged species. Depending on the existing coordination environment, the charge can be modified to generate species that can be cationic, anionic or neutral (Frezza et al., 2010). Most importantly, they form positively charged ions in aqueous solution that can bind to negatively charged biological molecules (Haas and Franz 2009). Relative to organic molecules, metal complexes can aggregate to a wide range of coordination geometries that give them unique shapes. The bond length, bond angle and coordination site vary depending on the metal and its oxidation state. In addition to this, metal-based complexes can be structurally modified to a variety of distinct molecular species that confer a wide spectrum of coordination numbers and geometries, as well as kinetic properties that cannot be realized by conventional carbon-based compounds (Yan et al., 2005). N Acetyl Cysteine has thiol group in its chemical structure which ligate with metal ions forming complexes. $\mathrm{N}$-acetylcysteine may have the dual function of carcinogenic and anticarcinogenic potentials. $\mathrm{N}$-acetyl cysteine inhibits human signet ring cell gastric cancer cell line (SJ-89). Also, increased the amount of 8-oxo-7,8-dihydro-2'-deoxyguanosine (8oxodG), a characteristic oxidative DNA 
Mosmann, T. (1983). Rapid colorimetric assay for cellular growth and survival: application to proliferation and cytotoxicity assays. J. Immunol. Methods.65: 55- 63.

Renzo Cini. (2000). Anti-inflammatory compounds as ligands in metal complexes as revealed in $\mathrm{X}$ ray structural studies, comments on inorganic chemistry.22:151-186.

Simon Simon Paul Fricker.(2007).Metal based drugs: from serendipity to designDalton Trans. , 4903-4917 DOI: 10.1039/B705551J.

YanYK,Melchart M, Habalemariam and Sadler PJ.( 2005).Organometallic chemistry,Biology and medicine;rutheniumarene ,anticancer complexes.chem common .(38);476476.
Haas KL and Franz KJ.(2009). Application of metal coordination chemistry to explore and manipulate cell biology.Chem Rev.;109(10):4921-60.

Kasai, H. S. Nalwa, H. Oikawa, S. Okada, H. Matsuda, N. Minami, A. Kakuta, K. Ono, A. Mukoh (1992). Handbook of Nanostructured Materials and Nanotechnology: Organics, polymers. Nakanishi, Jpn. J. Appl. Phys. 31, L1132.

Zhang L, FX Gu, JM Chan, AZ Wang, RS Langer and OC Farokhzad. (2007) Nanoparticles in Medicine: Therapeutic Applications and Developments. Clinical pharmacology DOI: 10.1038/sj.clpt.6100400

MeisterA,Anderson ME .(1983).Glutathione.Annu Rev Biochem. 52 :71760. 